\title{
Impoliteness, Mock-Impoliteness and \\ Underpoliteness Strategies in Abla Fahita's TV Show
}

Heba Abdelraheim Ibrahim Alkady

Assistant Professor, Faculty of Arts, South Valley University, Egypt.

\begin{abstract}
This paper is an attempt at exploring impoliteness strategies in the language of Abla Fahita's TV show (The Duplex). Abla Fahita is an online public figure on Egyptian social media, who has become an online 'millionaire'. The show gained popularity for its 'off-beat' utterances in mocking social issues. The Duplex currently plays a significant role in public discourse in Egypt. Impoliteness, mock
\end{abstract}

impoliteness and underpoliteness appear prominently in the Duplex with the intention (not) to cause offence. New vocabulary appeared having embarrassing connotations conceived of as a form of cooperative and simulated rudeness. Abla Fahita gives a new model of the MockImpolite or Underpolite Person.

Keywords: Impoliteness, Mock Impoliteness, Underpoliteness, Abla Fahita. 


\section{Impoliteness, Mock-Impoliteness and \\ Underpoliteness Strategies in Abla Fahita's TV Show}

Heba Abdelraheim Ibrahim Alkady

\section{Introduction}

Linguistic politeness maintains the social equilibrium and the friendly relations which enable us to assume that our interlocutors are being cooperative in the first place (Leech, 1983: 82). The most recurrent politeness studies are employed to maintain social harmony. Brown and Levinson (1987:1) believe that "politeness, like formal diplomatic protocol, presupposes that potential for aggression as it seeks to disarm it, and makes possible communication between potentially aggressive parties."

This study examines 131 extracts from Abla Fahita's TV show 'The Duplex'. The focus is on impoliteness incurred in a friendly setting of the Duplex. As a result of the analysis of the utterances, the paper uses another variety of impoliteness, namely 'mock impoliteness' and "underpoliteness".

The term "underpoliteness"' has first been introduced by Leech in his article "Pragmatic Principles in Shaw's You Never Can Tell" (1992). Leech defines it very briefly as "causing offence in all innocence" which is really "unwitting offense"' (Methias, 2011:16).

Methias believes that underpoliteness and mock-impoliteness are used without malice. They occur as a result of socializing habits (2011: 11). However, mock-impoliteness and underpoliteness generate feelings of embarrassment or unrest. Face embarrassment thus been deployed in two key ways in pragmatic research. In politeness research the focus has been on face threat avoidance or reduction, while impoliteness research has concentrated on deliberate or aggressive face threats, often glossed as either face attack or aggravation (Culpeper,2005:38; Limberg,2009:1376; Locher and Bousfield, 2008:3-4; Tracy,2008:175176). The analysis is made at the micro level of single utterances. Occasionally, utterances are taken into consideration for the reconstruction of the speech activity to assist determining the exact degree of offense incurred or not. The heart of this paper comprises analysis of impoliteness strategies in Abla Fahita's TV show 'The Duplex'.

\section{Impoliteness}

In order to define impoliteness, politeness must be introduced. Politeness might be defined as a means of minimizing confrontation in discourse - both the possibility of confrontation occurring at all, and the possibility that a confrontation will be perceived as threatening (Lakoff, 1989:102). Works related to impoliteness have noted that, 'compared to the robust literature about politeness, there is a paltry amount of literature concerning impoliteness' (Bousfield 2008a: 17). The notion of impoliteness is settled as the opposite of politeness. Politeness "maintain[s] the "social equilibrium and friendly relations" (Leech, 1983:82). Impoliteness creates social disorder. It is defined as "communicative strategies designed to attack face and thereby cause social conflict and disharmony.'(Culpeper et al., 2003: 1546). 


\section{Mock Impoliteness}

Culpeper states that it is "impoliteness that remains on the surface, since it is understood that it is not intended to cause offence" (1996: 352). Examples of bantering are "jihiddukum يعدكم," and ranistik w-Jarraftik آنستك وشرفتا which are uttered repeatedly by Abla Fahita to its audience and viewers as a way of bantering especially in contexts of competing against each other with insults.

Mock-impoliteness in Abla Fahita's show is not meant to be offending and the hearers can know this because the insults are clearly untrue. This kind of mock impoliteness used in Abla Fahita's show is categorized into negative and positive strategies (see Analysis and Categorization). Mock impoliteness can even show solidarity and reflect and foster social intimacy (Leech 1983, cited in Culpeper 1995: 352).

Leech defines banter as mock-impoliteness meant to encourage social harmony, yet does not readily define what mockimpoliteness means apart from stating it in terms of banter (1983: 254). Terkourafi (2008: 68) defines mock impoliteness as 'unmarked rudeness'. Furthermore, the closer the relationship, the less important politeness is. Intimate friends can be impolite towards each other. This is why one has to be careful with bantering if it is targeted towards people who are not very close to oneself. (Culpeper, 1995: 352$353)$.

\section{Underpoliteness}

Underpoliteness is to be considered as yet another variety of impoliteness. Malice and spite are not necessary prerequisites for underpoliteness. Not all offensive acts involve animosity or hatred. Underpoliteness is vivid in Abla Fahita's TV show as a means of creating broad viewing and intimacy. Rebuking or 
reproaching utterances like personalized negative vocatives:

$$
\begin{aligned}
& \text { زفت، مقصوف الرقبة، عنتيل، قطقوط، خر ع، ياولية، }
\end{aligned}
$$

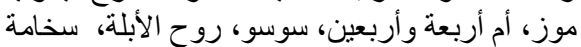

$$
\begin{aligned}
& \text { مقصوف ، البرك، ابن الحر امـ المجنونة، الحربوقة الأة }
\end{aligned}
$$

zift, marSouf lrraraba, 'antijl, raTru:T, Xiri ',ja wiljja, muzz, umm rarba'a warbi’aijn, su:su, ro:H lrabla, ma?Souf, , saxa:mit lbirak, ribnlHara:m-lmagnu:na, zilHarbu:sa, respectively.

Motherly corrective behaviour in Abla Fahita- Karo reproach (see Analysis below) as well as impoliteness employed in the episodes is free from spite. In spite of preaching or reproaching being "heavily offensive" (Kienpointner, 1997: 274), in this context it is rated as underpolite. It is intended for the long term benefit of 'Underpolitenes is not triggered by malice. In underpoliteness, "offence may be used to reinforce in-group solidarity. Offensive acts may be double edged. They may have a dual role. The very performance of an offensive act directed to a target may simultaneously serve to grease the wheel of talk or to enhance social relations" (Methias, 2011, 12-13).

In underpoliteness, offence may be used to underpin group harmony. A participant may perform a purposefully offensive act with the paradoxical aim of gaining a turn at talk or a chance to put in a word or to express solidarity. In underpoliteness, impolite acts may have an incidental element.

The offender performs an action "in spite of its offensive consequences though not out of spite" (Culpeper, 2005: 36). An adult may shame a child into doing something that will be of a long-term benefit to him. Shaming, reprimanding, rebuking, preaching and frightening are instances of underpoliteness when they occur as by-products of corrective behavior (Methias, 2011: 15).

Culpeper (2005: 40) proposes different types of face attack, namely: (1) attacks on quality face (2) attacks on social identity face, (3) attacks on equity rights, and (4) attacks on association right.

Politeness strategies are opposed to impoliteness strategies. To explain, opposition refers to both strategies orientation to face. Goffman (1967:213) defines face as "the positive social value a person effectively claims for himself by the line others assume he has taken during a particular contact." Accordingly, face is mutually constructed and sustained during social interactions.

Brown and Levinson (1987: 62) use the term MPs (Model Persons) who are willful and fluent speakers of a natural language, having two properties which are rationality and face. They distinguish two kinds of face:

negative face: the want of every 'competent adult member' that his actions be unimpeded by others.

positive face: the want of every member that his wants be desirable to at least some others.

Culpeper's (1996) paper 'Towards an anatomy of impoliteness' is the cornerstone of many studies of impoliteness. Culpeper refuses that impoliteness is 'marginal' in the social interaction. In contrary, it is an affecting phenomenon, which is the keystone of the language of Abla Fahita's program.

Culpeper proposes five super strategies that speakers use to make impolite utterances as follows:

1. Bald on record impoliteness: the FTA has a direct, clear, and unambiguous threat to the H's face in contexts where face is 
relevant and maximised. So, the attack of face occurs with the intention of the $\mathrm{S}$ to do the FTA (Culpeper, 1996; Culpeper, Bousfield and Wichmann, 2003).

2. Positive impoliteness: Archer (2008) assumes that when the FTA occurs to damage the positive face of the $\mathrm{H}$, it will be a positive impoliteness strategy. There are many other substrategies within this strategy, as follows:

- Ignoring and snubbing the other. The S fails to acknowledge the other's presence.

- Excluding the other participants from an activity.

- Dissociating from the other. The S denies association or common ground with the other; so he avoids sitting together.

- Being disinterested, unconcerned, unsympathetic.

- Using inappropriate identity markers. The $\mathrm{S}$ uses title and surname when a close relationship pertains, or a nickname when a distant relationship pertains.

- Using an obscure or secretive language. The S mystifies the other with jargon, or uses a code known to others in the group, but not the target addressee.

- Seeking disagreement. The S selects a sensitive topic.

- Making the other feel uncomfortable. The $\mathrm{S}$ does not avoid silence, joke, or uses small talk.

- Using taboo words - swearing, or using abusive or profane language.

- Calling the other names. The S uses derogatory nominations. (Culpeper, 1996).
3. Negative impoliteness: the FTAs that attack the negative face of the $\mathrm{H}$ are called negative impoliteness strategies (Culpeper, 2005). As with positive impoliteness, negative impoliteness also has substrategies as follows:

- Frightening. The $\mathrm{S}$ threatens others that some detrimental actions will occur to them.

- Condescending, scorning, or ridiculing. The $\mathrm{S}$ emphasizes your relative power. The $\mathrm{S}$ is contemptuous.

- Not treating the other seriously. The S belittles the other (e.g. using diminutives).

- Invading the other's space literally (e.g. position yourself closer to other than the relationship permits) or metaphorically (e.g. ask for or speak about information which is too intimate to be shared).

- Explicitly associating the other with a negative aspect. The $\mathrm{S}$ personalizes using the pronouns 'I' and 'you'.

- Putting the other's indebtedness on record (Culpeper, 1996).

4. Sarcasm or mock impoliteness: This strategy is all about insincerity, and what is performed is the opposite of what is meant. The superficial FTA used is a politeness strategy, and the polite meaning of this strategy remains on the surface, whereas the intended meaning is impolite. There is no specific strategy to be used. Many strategies can be used as acceptable ones, but deeply they may mean the opposite (Culpeper, 1996; Bousfield, 2008a; and Mohammed and Abbas, 2015).

5. Withhold politeness: As with the last strategy in Brown and Levinson's model of avoiding doing acts, this strategy is also about the avoidance of or failing in performing the polite strategy, the time it is expected to be performed. For example, 
when someone fails to thank somebody else for a favor or a present, it is interpreted as impoliteness (Culpeper, 1996; 2005; and Bousfield, 2008a).

\section{Aim of the Study}

This paper aims at analysing the utilization of Arabic mock-impoliteness and underpoliteness in Abla Fahita's TV show "The Duplex". It presents a linguistic analysis of impoliteness strategies exemplified in a sample of 131 utterances delivered by Abla Fahita, Karo, or the TV show guests. The paper is applied to a selected sample of corpora comprised of 131 Arabic lexis and utterances as shown in Analysis and Categorization. The sample is randomly selected to show the various linguistic patterns, of mock impoliteness and underpoliteness strategies of Arabic varities used in the program.

The study encompasses several domains including pragmatics (particularly impoliteness studies), and sociolinguistic studies. First and foremost this study adds value to previous researches of impoliteness and TV shows audience. Also, it enriches the Arabic studies with the newly interest of impoliteness and underpoliteness in up-to-date televised or online contexts. The study identifies the types of impoliteness strategies in the Arabic language used in Abla Fahita's show.

\section{Data Collection}

The researcher had a few options to study the impoliteness, mock impoliteness and underpoliteness strategies in the Duplex: either to focus on the conversations between Abla Fahita and her guests, Abla Fahita and audience, Abla Fahita and Karo, or Karo and the guests. With the help of Abla Fahita youtube channel (The Duplex) available on the Internet, the researcher transcribed the selected extracts that are all short utterances. Guests represent different kinds of age, gender, and social groups. The extracts are all from the episodes in seasons 2, 3, 4, and 6 . In total, there are dozens of conversations between Abla Fahita or Karo and the guests in all the six seasons, so the data had to be narrowed down. The full list of the Arabic extracts is provided in the appendix.

\section{Method of Analysis}

The researcher analysed the data by going through each of the transcribed extracts and finding all the cases when Abla Fahita or Karo or their guests say something that can be considered impolite, mock polite or underpolite. Then she categorized all the cases according to Culpeper's strategies of impoliteness and Leech's rarely tackled variety 'underpoliteness'.

Turning now to the data, we can see the theoretical principles discussed above at work. The researcher will offer a table of Arabic extracts of 131 words or utterances (see Appendix) delivered by Abla Fahita or Karo or their various guests. The motivation for this is that, as suggested above, mock-impoliteness and underpoliteness are parasitic on impoliteness; thus an analysis of mockimpolite or underpolite turns is predicated on a baseline description of impolite turns.

\section{Analysis and Categorization}

The analysis and classification of the Duplex utterances are done in accordance with Culpeper's impoliteness strategies. Culpeper (1995:356) has summarized Brown and Levinson's list of five strategies for doing FTAs as follows:

1) Bald-on-record strategies: The FTA is performed 'in the most direct, clear, unambiguous and concise way possible' (Brown and Levinson 1987: 69). 
2) Positive politeness: The use of strategies designed to redress the addressee's positive face wants.

3) Negative politeness: The use of strategies designed to redress the addressee's negative face wants.

4) Off-record: The FTA is performed in such a way that "there is more than one unambiguously attributable intention so that the actor cannot be held to have committed himself to one particular intent" (Brown and Levinson: 1987: 69).

5) Withhold the FTA. (Culpeper 1995: 356.)

\section{The strategies and the substrategies used in the Duplex}

1) Bald on Record Impoliteness:

The FTAs are performed in the most direct, unambiguous and shocking ways as exmplified in thse use of words and utterances like, rum sfaltak,

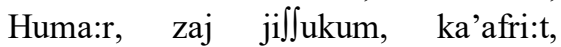
rabi:Ha, um ili gabitkum, and jixrib beit rumk as shown in the utterances below. The speakers use expressions that are quite rude by Arabic Egyptian norms. Speakers and hearers are familiar with the impolite load of the expression in Egyptian Arabic, so there was no escalation of conflict.

1) يخرب بيت ام ئ juxrib beit rum sfaltak سفالتئ

2) خمار

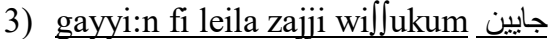
في ليله ذي وشكم,

4) huwwa inti nawja tkamili: m'aaja ka'afri:t waln jantahi 'aadhab

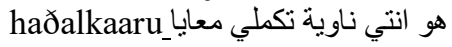

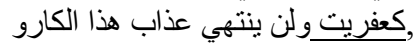

5) 'aru:sa wrabi:Ha عروسة وقبيحيه

6) umukum w um ili gabitkum امكم وام اللي جابتك,
7) ماما قبيحه ,انا عارف

8) jixrib beit 2umk يخرب بيت امك :,

2) Positive Impoliteness:

Positive impoliteness strategies in Abla Fahita's program are classified into sub-strategies as follows:

a- The use obscure or secretive language - for example, mystify the other with jargon, or use a code known to others in the group, but not the target.

This substrategy is very common in the Duplex. Based on the hearers' facial expressions, the utterances do not seem to be teasing.

The utterances include unclear and mostly odd Arabic lexical items (verbs or nouns) as follows:

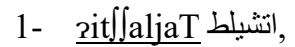

2- Hatitnifix

3- fahitaja:gra Habaja tammam wa allah yirrHam sil madaam فاهيتايجر ا حباية تمام والله يرحم المدام

Using odd morphological structures (adding Arabic feminine taas to inanimate nouns or proper nouns):

$$
\begin{aligned}
& \text { 4- 2ittilifizjo:na التليفيزيونة } \\
& \text { 5- 2ilweiba الويية } \\
& \text { 6- fein rizi:sa fein Hat fibsu:ta } \\
& \text { فين إيزيسة فين حتشبسونة }
\end{aligned}
$$

b- The use of inappropriate identity markers -

'Call the other names' is one of the substrategies used in the Duplex. For example using titles and surnames when a (close) relationship pertains, or a nickname when a distance relationship pertains. Based on the speakers' and hearers' facial expressions, the utterances do not seem to be teasing. The interesting thing is that the intonation and enthusiasm of melody 
achieved the positive aspect of 4impoliteness. Examples:

1.

ي بقي فلول و لا مرنتيين walla murta $\iint_{\mathrm{i}: \mathrm{n}}$

2.

2ililara لقرشانات

3. بقياده المايسترو سليم ضبابBiqija:dit

ilmajistru sli:m Daba:b

c- The use taboo words or expressions (embarrassing) or abusive or profane language is very clear in the Duplex. The speakers used expressions that are quite badmannered by Egyptian norms. Both interlocutors are familiar with the impolite load of the expressions in Egyptian Arabic, so there was no escalation or conflict. The hearers recognize the possible emotional/aggressive load of speakers' prior utterance and respond by laughter.

The speakers and the hearers are familiar with the socio-cultural load of the expressions and act accordingly: no escalation or conflict. If, however, not each interlocutor is familiar with the impolite load of formulae, misunderstanding may occur.

The underlined words are examples of socially embarrassing and unacceptable Arabic words:

قعدوه علي الخازوق-1

ra'aaduh 'aala pilxazzou?

يا خبر ده اغتصاب جماعي لا لا لا تحرش جامد

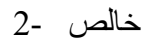

ja xabbar da pightiSab gama:'i: la la la

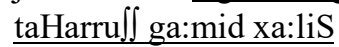

حتعطلي زي السنة اللي فاتت ؟ و أوسخخ

hati'amili zajji issana lli fa:tit wizawsax

jazamil

تنبوز, تكرع -5

tibawiz tikara'a

احيه-6

raHeih

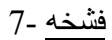

fa $\int \mathrm{xa}$

8امل اتخانق مع زميله جاب البو اسير

'aamil pitxaanis ma'aa zmi:lu gab

2ilbawasi:r

9- بحب لبنان علثان الفشخ مش عيب عندكم

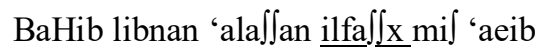
'andukum

بالنسبة للايح ايح-10

bilnisba lilaih $2 \mathrm{iH}$

علي الكبري متحير و عايز يتسير-11

'alaa ilkubri mitHajar wi'aajiz

jitsaijar

القصرية الثقية إإح ليك وليا -12

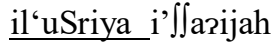

irH li:k willja

أردافي ملظلظة -13

pardafi mlzZhlaZhah

هترمي الحلق علثان شخه في الكابينيه -14

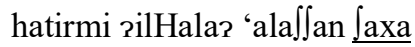

filkabineih

صحباتي لما عرفوا انكك جاي بعتو ا اسئلة و رسائل

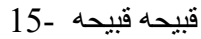

SaHba:ti lamma 'irfu innak gaaj

ba'atu rasrila wrasa:jil rabi:Ha

zabi:Ha

اتفها من بؤي -16

ratiffaha min buraij

مفرد كلمه بز ابيز -17

mufrad kilmit bzabi:z

3) Negative Impoliteness:

The negative mock-impoliteness substrategies used in the Duplex are: 
a- Frightening or threatening

The following underlined extracts are examples of threatening and frightening acts:

شماعه ولا شبشب !-1

$\iint$ ama'aa wala $\iint_{i b \int i b !}$

نديكو ا بالحضن و لا نديكو ا بالثبشب-2

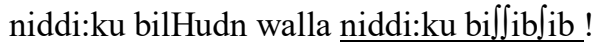

The speakers and hearers are familiar with the innocent and not really offending impoliteness of the expressions in Egyptian Arabic, so there is no conflict. Although the speaker's expressions seem to carry a possible "escalatory" or even "motherly bantering" attitude, the hearers attempt to deescalate the banter by smiling and laughter.

b- Condescending, scorning, and ridiculing are also very common in the Duplex. The speaker emphasizes relative power. The audience and hearers were familiar with the impolite load of the underlined expressions in Egyptian Arabic, so there was no offence or conflict. Speakers and hearers were aware of the socio-cultural loads of the expressions and act accordingly: no escalation of conflict because of the hearers's appropriate response 'laughter'. If, however, not each interlocutor is acquainted with the impolite loads of utterances, misunderstanding may occur. The underlined extracts show the use of this substrategy:

خدي الثر وروحي -1

xudi ai $\iint a r$ w-ru:Hi

كارو يفصل جهاز التنفس الصناعي و مامته

تموت ذي بابته ويطلع في اعلانات
رمضان -2 ويبقي يتيم مشهور ويتبني اسره

جديده ويبتدي علي نضافة

Karo jifSil giha:z ittanaffus

iSSina:'i: $w$ - mammtu tumu:t

zajji babtu w-jiTla' fi rilana:t

ramadan w- jibra jati:m ma $\int$ hu:r

w-jibtidi 'ala naDa:fa

يلا ياحبيتى انستلك وشرفتلك -

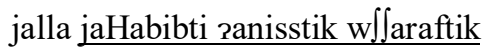

ودينى المقبره العب دع بابا -4abal

wddiini lmarbara ral'ab ma'a

$\underline{\text { ba:ba }}$

c- Invading others' space or privacy is also one of substrategies used in the Duplex. To invade the other's space in public-literally (e.g. position yourself closer to the other than the relationship permits) or metaphorically (e.g. ask for or speak about information which is too intimate given the relationship (eg. female/male body parts, underwear, homewear, urination...). According to Egyptian Arabic norms, the underlined extracts are examples of invading others' space substrategy.

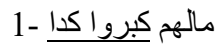

malhumm kibbru kidda

احمد لابس بوكسر لونه ايه -2

raHmad la:bbis buksr lounu rih

لو الباروكه بتهرشك فكي كدا وخدي راحتي

ورحرحيى

law lbbarau:kka bituhr $\iint_{\text {ik fukki }}$

kidda w xuddi ra:Htik wrHrHi:

4- احمد عنده حسنه مستخبية فين؟

raHmad 'andu Hassana

mistixabija fejn

5ترقلها باليه بالثورت

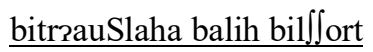

امتي اخر مره حمادة قص اظافر رجله او

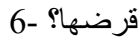


mi:n waxdda Halawa rabl mati:gi

Tajjib mi:n ffatla

مين بيلبس بوكسر مين بيلبس سليب -24

يبقي الباقي مش بيلبس حاجة -25

jibra lbaari mi $\iint$ bijilbbis Ha:ga

عمليات جر احية كبرت تيك ووناك -26

'amalija:t graHijjah kabrrit ti:k w$\underline{\text { taak }}$

4) Sarcasm or Mock Impoliteness:

The following examples include underlined utterances. They are superficillay innocent and polite, but the intended meaning is impolite:

اتاري المرحوم قالع الفانلة ومانشي

ratari ilmarHu:m raalia' rilfanilla wma: $\iint \mathrm{i}$ bissilib

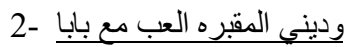

waddiini rlmasbara rala'ab $\underline{\text { ma'a ba:ba }}$

'aamallti Hammam rinahrda

اي منطقة بتغير فيها في جسمك -16

2aj mantira bitghi:r fiha fi gismk

مزنوقه -17

mazznu:ra

مره اتزنقت -18

$\underline{\text { marra ritzanna?t }}$

اتزنقت زنقة مالهاش حل -19

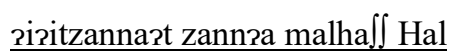

عندك بوكسر مخروم -20

'aandak bukksr maxru:m

مين ممكن تعمل بو مبة قدامها - 21 مئس

$\underline{\text { mi:n mumkin ti'ammil bomba }}$

pudamha

مهتم بالنص اللي فوق بس -22

muhttam bilnuSS pilli fous bas

مين و اخده حلاوة قبل ما تيجي طيب مين فتلة -23
حاطه كير اتين مش معقول ده من

3- النوع الرخيص منول دن من

HaTTa kijrjatin mif ma'azu:1 da min rilnu'a zilrixiS

4- You should visit pyramids everything is very nice I am sample

برفانتك حلوه خالص ده عطر

قريش -5 دمبر

barfanatak Hilwa xaaliS da

'iTr quraj」

2-6 -

di mi raghani Tifl di raghani

muTala?

حماده تقرب لنجلاء بدر او مصطفي قمر او

7تي النجمه الذهبية النير 
حباية فاهيتا ياجر اللسعاده الزوجية - 21

Habajit fahita jaagra lilsa'ada

rilzawgija

آدم أعظم الثذييات -22

radam ra'Zam ri ${ }^{\text {eө} a d j i j j a: t ~}$

المنتج المصري بيقولو بيكرمش وبيمط -23

pilmuntag pilmaSrj bijp u:lu

bijkarmif wbijmuTT

هانش اتاك -24

han $\iint$ ratta:k

متجيب استثمار ونجيب منار -25

matgi:b istiema:r wingijb mana:r

مصريتنا وطنيتنا حماده هلال حماده هلال -26

maSrijjitna waTatnijjitna hama:da hila:1 hama:da hila:1

5) Underpoliteness Strategies:

Underpoliteness is very clear in Abla Fahita's TV show as a means of creating broad viewing and solidarity.

The derogatory names given below are considered as innocent rudeness or banter by Egyptian norms. Reproaching and mother daughter intimidations have underpolite implied meanings in Egyptian norms, so there is no real offence or malice. The hearers recognize the possible emotional loads of the speakers' utterances. Underpoliteness is really vivid in Egyptian Arabic.

The following examples include underlined derogatory nominations, intimidations and reproaching. They appear as part of corrective behaviour among Abla- Fahita, Karo, guests and viewers. Underpoliteness is one of the cornerstones of the Duplex credit.

ماما هو انتي كدا حتبقى مرحومة وتقابلى

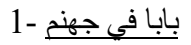

fifj ta'bana wlazim tdjlha Hurana 'ilman

biranna pilHuarna 'aDal wfifj wakla

$\underline{\text { krumb }}$ 
'aajzi:n nifuf ilbayaDa pilHilwa di

ma:ma huwwanti kida Hatibri

marHu:ma witrabli ba:ba fi

gihannam

2- شايله فلوسك وصيغنك فين

\ajla flu:sik wSightik fein

البنت تقول لمامتها الحربوقة وهي بتموت -3

sil-bint tizu:1 limamitha 1Harbu:sa w-hijja bitmu:t

استنطقوكي في قسم

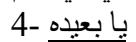

ristanTaru:ki fi rism ja b'i:da

5ا ماترحمني يا بعيده

matraHamti ja b'i:da

يابن الحر ام -6

jabni lHara:m

هو انتي بتقري علي سمانتي -

huwwanti bitzurri 'ala simmanti

8- منر ونص سمانه

mitr wnuSS sima:na

يا سوسو -9SS

ja su:su

لبسك عره خالص -10

libsik 'irra xaaliS

قراره ياختي - 11

2arrara jaxti

مش كبرتي عالهبل ده -12

mil kibirti 'alhabal da

مش معقو له الجاكته جبتها من مر اتلك ولا لا

13-13 منين

mil ma'roula ril3akita gibtaha

min miratak wala mnejn

14- You married good bye

يانصبتي ده عايز يشقط بنته -15

janSibti da 'aajiz ji $\int_{\text {raoT bintuh }}$

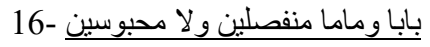

baba w mama munfaSili:n wala

maHbusi:n

اهرشلى ضهري -17

uhrufli Dahri

عايزين نشوف البياضه الحلوه دي -18
حقائق ذي الطين لظافر عابدين -19 حل

Haqairiq zai elTi:n liZHafir

'aabdi:n

بتحب البنت اللى.... ها كبيره -

bitHib ilbint rili... ha kibi:ra

ايه الحاجه اللي تنكسف توريها في ني

جسمك - 21

?ih zilHaga illj titkisif twarjha fi

gismk

عارفه انك مش مؤدبه -22

'aarfa inik mi muraadaba

ور اء كل انكل عظيم طنط -23

waraas kul rankle "azheem TanT

وور اء كل طنط عظيمة نفسها وشويه

ميكب -24 نفئا

wiwaraa? Kul Tant 'azhi:ma

nafsaha wfwjt

مامتك عروسه محثية قطن -25

mamtik 'aarusa maH]iya rutn

اقفل رجليك -26 اقد

2irfil riglejk

ياخا شوف تو اليت -27

jaxa Jouf tuwilit

يخرب بيت جمال امك -28

jixrib bijt gamal 'umak

امك مربتكيش-29

?umik marbitkj]

احكيلي حكاية من اياهم -30

riHki:li Hika:ja min iyya:hum

بلع كارو ياسخامه البرك - 31

saxamit il birak

كم عدد المقاريض /شاحطة كبيره / حلوفه

كبيره -32/ كلهن

Kam 'aaddad ilmarari:D /

〔aHTTa kbijra /Halu/;fa kbijra

ياوليه-33

ja wilja

يابن السوكه -34 
is presented and analysed. Impoliteness and underpoliteness are incurred in a very friendly setting of the Duplex.

2- The Arabic variety used in the Duplex is rich of communicative sources that can be used as underpolite or mockimpolite strategies like personalized negative vocatives:

$$
\text { ولية، امفت، يا مقصوف واربعين يا بعيده، عنتيل، قطقوط، خرع، يا }
$$

38- $\underline{\Sigma \varepsilon}$

sum rarba'a wirbi'ajjn

The underlined underpolite utterances are not motivated by malice or hatred and are socially acceptable according to expected Egyptian norms of behavior.

It is important to note that the analysis is not a comprehensive or detailed account of impoliteness and mock-impoliteness or underpoliteness in the Arabic utterances shown in the Duplex. Such an account would be extremely difficult. Rather, the analysis is intended to categorize these extracts. Nevertheless, these examples do shed light on some of the possible strategies interlocutors can use to express impoliteness and mock-impoliteness or underpoliteness.

\section{Results and Conclusion}

The study concluded the following results:

1- In this study "underpoliteness" as a rarely studied variety of impoliteness
3- Underpolite communicative acts are not motivated by malice, spite or hatred and are socially acceptable according to expected norms social of behaviour. Reproaching, derogatory nominations and intimidations have been classified as underpolite when they appeared as part of corrective behaviour among the Duplex characters, viewers and guests.

4- Underpoliteness, Negative Impoliteness, Mock Impoliteness, Positive Impoliteness, and Bald on Recod impoliteness are the cornerstones of the Duplex credit and success. The strategies are arranged accordingly depending on the number of their ocurrences in the Duplex.

5- This study tackled 131 utterances realizing impoliteness strategies in four seasons of the Duplex TV show. The configuration of five strategies realized by the extracts exploited is as follows:

\begin{tabular}{|l|c|c|}
\hline \multicolumn{1}{|c|}{ Strategy } & Frequency & Percentage \\
\hline Underpoliteness & 38 & $28 \%$ \\
\hline Negative Impoliteness & 33 & $24 \%$ \\
\hline Positive Impoliteness & 26 & $19 \%$ \\
\hline Mock Impoliteness & 26 & $19 \%$ \\
\hline Bald on Record Impoliteness & 8 & 10 \\
\hline
\end{tabular}


The following chart represnts the average and percentage of the five strategies found in the Duplex:

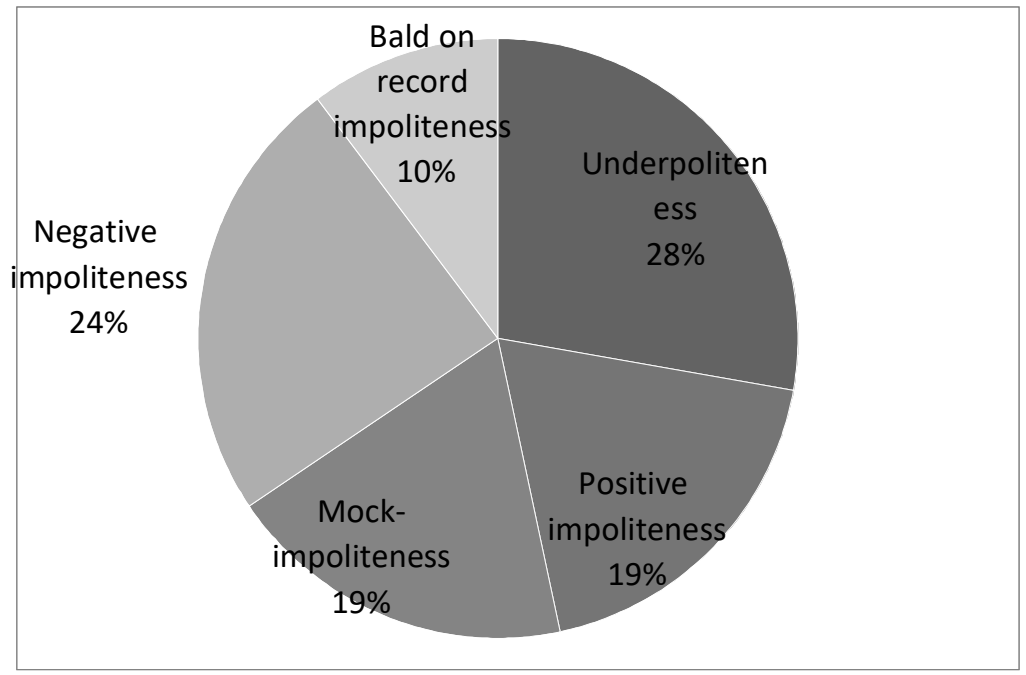

6- Underpoliteness represents the dominating percentage among others. The focus on underpoliteness incurred in the friendly settings of the Duplex underpins harmony among Abla Fahita as a Model Person, Karo as another Model Person and the audenice or guests.
7- As a result of the analysis of the utterances, the paper uses another variety of impoliteness, namely mock impoliteness and "underpoliteness".

8- Negative impoliteness comes next to underpoliteness. Positive and mock impolitenesses present the same average while Bald on record impoliteness forms the least percentage of the Duplex. 


\section{References}

Allan, K. and Burridge, K. (2006). Forbidden words: Taboo and the Censoring of Language. Cambridge: Cambridge University Press.

Archer, D. E. (2008). Verbal aggression and impoliteness: Related or synonymous?'. In Bousfield, Derek, and Locher, Miriam A. (eds.) Impoliteness in Language: Studies on its Interplay with Power in Theory and Practice. Berlin and New York: Mouton de Gruyter.

Bousfield, D. (2008a) Impoliteness in Interaction. Amsterdam: John Benjamins Publishing Company.

Bousfield, D. (2008b). Impoliteness in the struggle for power. In Bousfield, Derek and Locher, Miriam A. (eds.) Impoliteness in Language: Studies on its Interplay with Power in Theory and Practice. Berlin and New York: Mouton de Gruyter.

Brown, Penelope, and Stephen C. Levinson. (1987). Politeness: Some Universals in Language Use. Cambridge: Cambridge University Press.

Culpeper, J. (1995). In: Handbook of Pragmatics. Amsterdam: John Benjamins p. 513-520.

Culpeper, J. (1996). Towards an anatomy of impoliteness. Journal of Pragmatics 25, 349367.

Culpeper, Jonathan, Bousfield, Derek and Wichmann, Anne. (2003). Impoliteness revisited: With special reference to dynamic and prosodic aspects. Journal of Pragmatics 35, 1545-1579.

Culpeper, J. (2005). Impoliteness and entertainment in the television quiz show The Weakest Link. Journal of Politeness Research 1, 35-72.

Goffman, E. (1967). Interaction Ritual. Essays in Face-to-Face Interaction. Chicago: Aldine, pp. 113-136.

Kienpointner, Manfred. (1997). Varieties of rudeness: types and functions of impolite utterances. Functions of Language 42, 251-287.

Lakoff, R. (1989). The Limits of Politeness: Therapeutic and Courtroom Discourse. Multilingua 8, 101-129.

Leech, G., Short, M., (1981). Style in Fiction: A Linguistic Introduction to English Fictional Prose.London and New York: Longman.

Leech, Geoffrey. (1983). Principles of Pragmatics. London and New York: Longman.

Limberg, Holger (2009). Impoliteness and threat responses. Journal of Pragmatics 41, 13761394.

Locher, Miriam and Bousfield, Derek. (2008). Introduction: Impoliteness and power in language. In: Locher, Miriam, Bousfield, Derek (Eds.), Impoliteness in Language. Berlin: Mouton de Gruyter, pp. 1-13. 
Locher, Miriam, and Richard Watts. (2008). Relational work and impoliteness: Negotiating norms of linguistic behavior. In D. Bousfield \& M.A. Locher (eds.), Impoliteness in Language: Studies on its Interplay with Power in Theory and Practice, pp. 77-101. New York: Mouton de Gruyter.

Methias, Norice (2011). "Impoliteness or Underpoliteness: An analysis of a Christmas dinner scene from Dickens's Great Expectations." Journal of King Saud University - Languages and Translation 23, 11-18.

Mohammed, H. N., \& Abbas, N. F. (2015). Pragmatics of Impoliteness and Rudeness. American International Journal of Social Science, 4(6), 195-205.

Terkourafi, Marina. (2008). Toward a unified theory of politeness, impoliteness, and rudeness. In D. Bousfield and M. Locher (eds.), Impoliteness in Language: Studies on its Interplay with Power in Theory and Practice, pp. 45-76. New York: Mouton de Gruyter.

Tracy, Karen. (2008). "Reasonable hostility: Situation-appropriate face-attack.” Journal of Politeness Research 4, 169-191.

Watts, Richard J. (2003). Politeness: Key Topics in Sociolinguistics. Cambridge: Cambridge University Press. 


\section{Phonemic Symbols}

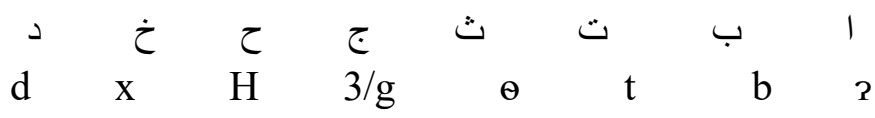

$$
\begin{aligned}
& \begin{array}{lllllll}
ض & \omega & \omega & j & \jmath & j \\
D & S & \int & S & Z & r & \partial
\end{array}
\end{aligned}
$$

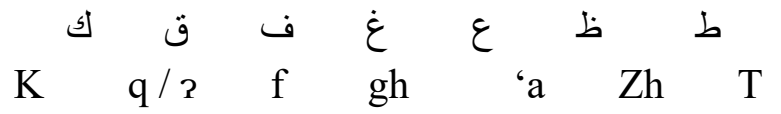

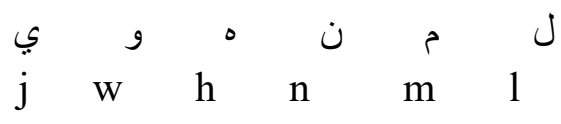

$$
\begin{aligned}
& \text { a } \\
& \text { اضكمة } \\
& \text { i }
\end{aligned}
$$

Cairene "قج" and are pronounced as /2/ and /g/ respectively. 


\section{Appendix}

\section{Arabic Extracts from Abla Fahita's TV Show}

The following table includes a list of 131 various Arabic extracts taken from Abla Fahita's TV show. The speaker $(\mathrm{S})$ and hearer $(\mathrm{H})$ of each extract are identified. All extracts are transcribed.

\begin{tabular}{|c|c|c|c|}
\hline No. & Speaker (S) & Hearer (H) & Utterance \\
\hline 1. & Abla Fahita & $\begin{array}{l}\text { Maged } \\
\text { Elmasry }\end{array}$ & $\begin{array}{c}\text { يخرب بيت ام سفالتاك sfaltak } \\
\text { jixrib beit sum sit }\end{array}$ \\
\hline 2. & Abla Fahita & $\begin{array}{l}\text { Maged } \\
\text { Elmasry }\end{array}$ & 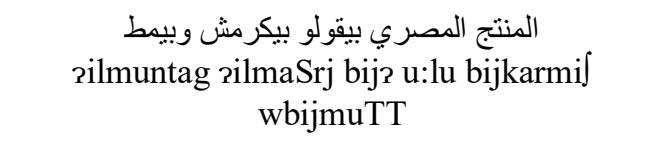 \\
\hline 3. & Abla Fahita & $\begin{array}{l}\text { Maged } \\
\text { Elmasry }\end{array}$ & $\begin{array}{c}\text { مهتم بالنص اللي فوق بس } \\
\text { muhttam bilnuSS rilli four Bas }\end{array}$ \\
\hline 4. & Abla Fahita & $\begin{array}{l}\text { Maged } \\
\text { Elmasry }\end{array}$ & 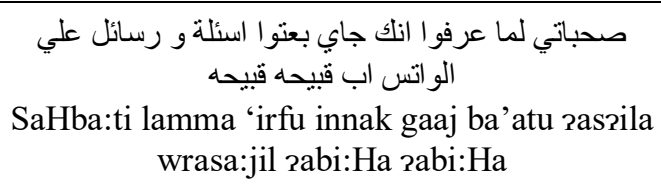 \\
\hline 5. & Abla Fahita & $\begin{array}{l}\text { Maged } \\
\text { Elmasry }\end{array}$ & $\begin{array}{c}\text { منجيب استثمار ونجيب منار } \\
\text { matgi:b istiema:r wingijb mana:r }\end{array}$ \\
\hline 6. & $\begin{array}{l}\text { Maged } \\
\text { Elmasry }\end{array}$ & Abla Fahita & 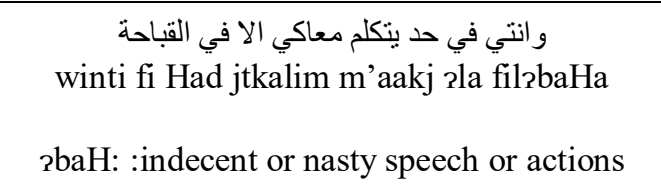 \\
\hline 7. & Abla Fahita & Hany Ramzy & $\begin{array}{c}\text { هانش اتالك } \\
\text { han } \iint \text { ratta:k }\end{array}$ \\
\hline 8. & Abla Fahita & Hany Ramzy & حمارHuma:r \\
\hline 9. & Hany Ramzy & Abla Fahita & 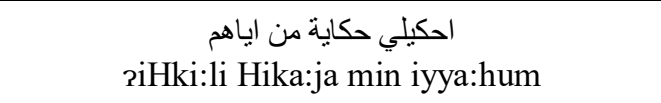 \\
\hline 10. & Abla Fahita & Audience & جاين في ليله ذي وشكم \\
\hline 11. & Abla Fahita & Audience & 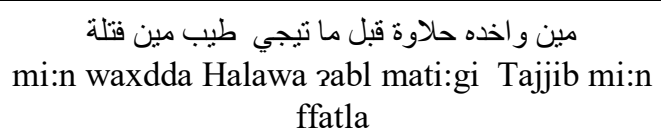 \\
\hline
\end{tabular}




\begin{tabular}{|c|c|c|c|}
\hline 12. & Abla Fahita & Audience & $\begin{array}{c}\text { مين بيلبس بوكسر مين بيلبس سليب } \\
\text { mi:n bijilbbis bukssar mi:n bijilbbis slib }\end{array}$ \\
\hline 13. & Abla Fahita & Audience & 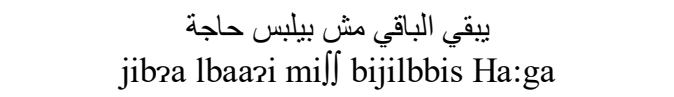 \\
\hline 14. & Karo & Abla Fahita & 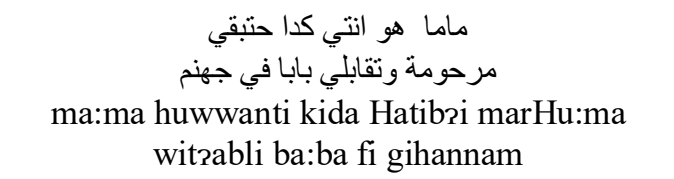 \\
\hline 15. & Karo & Abla Fahita & $\begin{array}{c}\text { شايله فلوسك وصيغنك فين:sik wSightik fein } \\
\text { Jajla flu:sik }\end{array}$ \\
\hline 16. & Karo & Abla Fahita & $\begin{array}{l}\text { مينفعش اقولك خدي الثر وروحي } \\
\quad \text { xudi ai } \iint \text { Jar w-ru:Hi }\end{array}$ \\
\hline 17. & Karo & Abla Fahita & 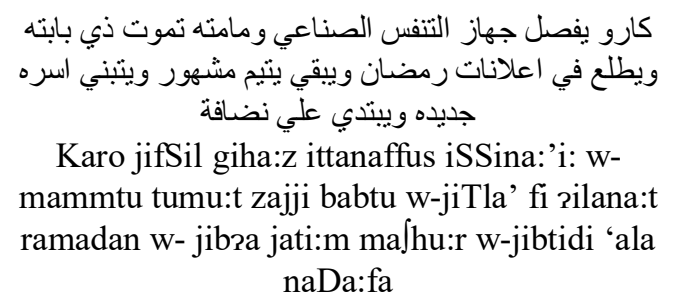 \\
\hline 18. & Karo & Abla Fahita & $\begin{array}{c}\text { مصريتنا وطنيتنا حماده هلال حماده هلال } \\
\text { maSrijjitna waTatnijjitna hama:da hila:1 } \\
\text { hama:da hila:1 }\end{array}$ \\
\hline 19. & Karo & Abla Fahita & $\begin{array}{c}\text { هو انتي ناوية تكملي معايا كعفريت ولن ينتهي عذاب هذارو } \\
\text { huwwa inti nawja tkamili: m’aaja ka'afri:t waln } \\
\text { jantahi ‘aadhab haðalkaaru }\end{array}$ \\
\hline 20. & Karo & Abla Fahita & $\begin{array}{c}\text { البنت تقول لمامتها الحربوفة وهي بتموت } \\
\text { 2il-bint tizu:llimamitha lHarbu:ra w-hijja } \\
\text { bitmu:t }\end{array}$ \\
\hline 21. & Abla Fahita & Karo & $\begin{array}{c}\text { استتطقوكي في قسم يا بعيده } \\
\text { 2istanTa2u:ki fi 2ism ja b’ai:da }\end{array}$ \\
\hline 22. & Abla Fahita & Hana sheha & $\begin{array}{c}\text { عمليات جر احية كبرت تيك ووناك 'amalija:t graHijjah kabrrit ti:k w-taak } \\
\text { 'amah }\end{array}$ \\
\hline 23. & Abla Fahita & Karo & $\begin{array}{c}\text { ما اترحمتي يا بعيده } \\
\text { matraHamti ja b'ai:da }\end{array}$ \\
\hline 24. & Abla Fahita & Audience & $\begin{array}{c}\text { يابن الحرا } \\
\text { jabin lHara:m }\end{array}$ \\
\hline 25. & Karo & Audience & 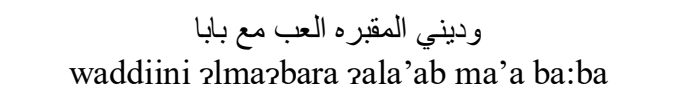 \\
\hline
\end{tabular}




\begin{tabular}{|c|c|c|c|}
\hline 26. & Abla Fahita & Audience & $\begin{array}{c}\text { التليفيزيونة } \\
\text { Rittilifizjo:na }\end{array}$ \\
\hline 27. & Maya Diab & Abla Fahita & $\begin{array}{c}\text { عروسة وقبيحه:Ha } \\
\text { ‘aru:sa wrabi:Ha }\end{array}$ \\
\hline 28. & Maya Diab & Abla Fahita & $\begin{array}{c}\text { هو انتي بتقري علي سمانتي 'ala simmanti } \\
\text { huwwanti bit2urri 'ala }\end{array}$ \\
\hline 29. & Abla Fahita & Maya Diab & $\begin{array}{l}\text { متر ونص سمانه } \\
\text { mitr wnuSS sima:na }\end{array}$ \\
\hline 30. & Abla Fahita & Ahme Fahmy & يا سوسو j ja su:su \\
\hline 31. & Abla Fahita & Ahme Fahmy & 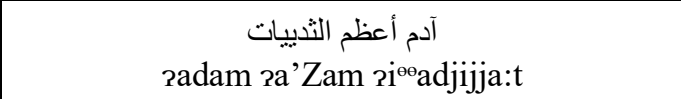 \\
\hline 32. & Abla Fahita & Audience & 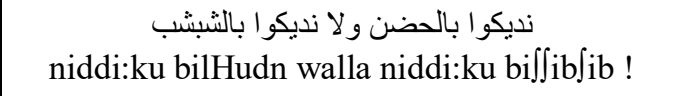 \\
\hline 33. & Abla Fahita & Audience & $\begin{array}{c}\text { الويبة } \\
\text { 2ilweiba }\end{array}$ \\
\hline 34. & Abla Fahita & Audience & $\begin{array}{c}\text { فين إيزيسة فين حتشبسوتة } \\
\text { fein 2izi:sa fein Hatjibsu:ta }\end{array}$ \\
\hline 35. & Abla Fahita & Audience & $\begin{array}{c}\text { حظلك من هانثك } \\
\text { HaZak min hanfak }\end{array}$ \\
\hline 36. & Abla Fahita & Audience & $\begin{array}{c}\text { بقياده المايسترو سليم ضباب } \\
\text { Biqija:dit ilmajistru sli:m Daba:b }\end{array}$ \\
\hline 37. & Abla Fahita & Ahmed Fahmy & 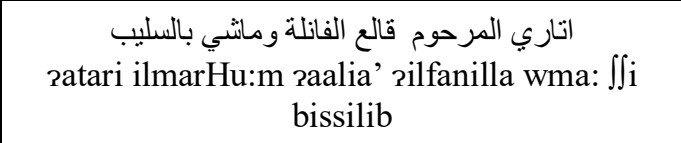 \\
\hline 38. & Abla Fahita & Audience & 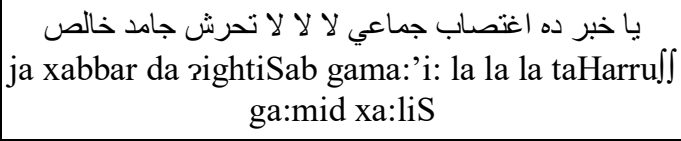 \\
\hline 39. & Abla Fahita & Audience & 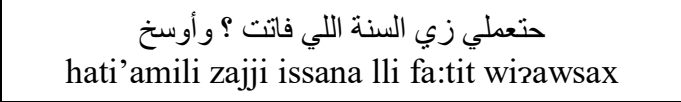 \\
\hline 40. & Abla Fahita & Audience & $\begin{array}{c}\text { لبسك عره خالص 'irra xaaliS } \\
\text { libsik “irra }\end{array}$ \\
\hline 41. & Hala Sarhan & Abla Fahita & 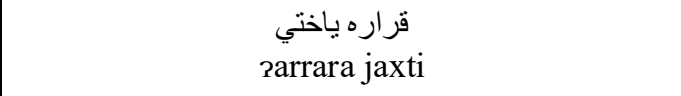 \\
\hline 42. & Abla Fahita & Audience & 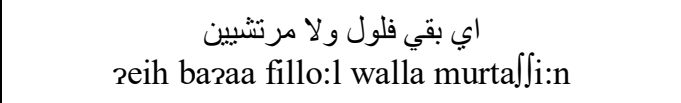 \\
\hline 43. & Abla Fahita & Audience & $\begin{array}{c}\text { مش كبرتي عالهيل ده 'alhabal da } \\
\text { mil kibirti 'ali }\end{array}$ \\
\hline
\end{tabular}




\begin{tabular}{|c|c|c|c|c|}
\hline 44. & & Abla Fahita & Audience & 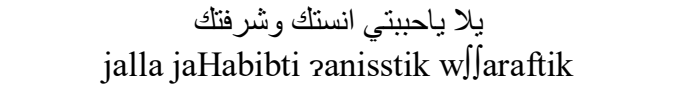 \\
\hline 45. & & Abla Fahita & Audience & $\begin{array}{c}\text { مالهم كبروا كدا } \\
\text { malhumm kibbru kidda }\end{array}$ \\
\hline 46. & $\mathrm{p}$ & Abla Fahita & Audience & $\begin{array}{c}\text { مش معقو له الجاكته جبتها من مر اتلك و لا منين ma'roula ril3akita gibtaha min miratak } \\
\text { wala mnejn }\end{array}$ \\
\hline 47. & & Abla Fahita & Audience & You married good bye \\
\hline 48. & & Abla Fahita & Audience & $\begin{array}{l}\text { You should visit pyramids everything is very } \\
\text { nice I am sample }\end{array}$ \\
\hline 49. & & Abla Fahita & Audience & 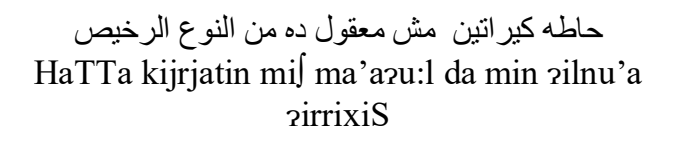 \\
\hline 50. & & Abla Fahita & Audience & $\begin{array}{c}\text { برفانتاك حلوه خالص ده عطر قريش } \\
\text { barfanatak Hilwa xaaliS da 'iTr quraj }\end{array}$ \\
\hline 51. & & Abla Fahita & Ahmed Noor & $\begin{array}{c}\text { القرشانات } \\
\text { 2ilsara }\end{array}$ \\
\hline 52. & & Karo & Hamada Helal & $\begin{array}{c}\text { دي مش اغاني طفل دي اغاني مطلق di mi raghani Tifl di raghani muTalar } \\
\text { di raghi }\end{array}$ \\
\hline 53. & & Karo & Hamada Helal & $\begin{array}{c}\text { حماده تقرب لنجلاء بدر او مصطفي قمر او حتي النجمه } \\
\text { Hamada tirrab linaglaaa badr raw muSTafa } \\
\text { ramar raw Hatta lnigma izhabja }\end{array}$ \\
\hline 54. & & Abla Fahita & $\begin{array}{l}\text { Nicola } \\
\text { Moawed }\end{array}$ & 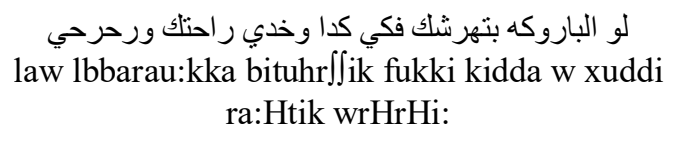 \\
\hline 55. & & Abla Fahita & Amr Mostafa & 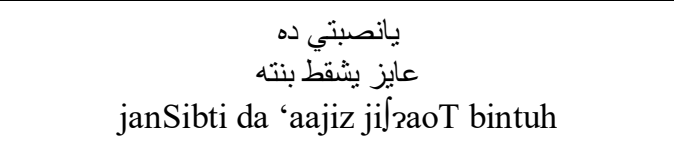 \\
\hline 56. & & Abla Fahita & Amr Mostafa & $\begin{array}{c}\text { شدينا السيفون علي الماضي 'ala il maDy } \\
\text { Jadijna rilsifon 'ala }\end{array}$ \\
\hline 57. & & Abla Fahita & Amr Mostafa & $\begin{array}{c}\text { بيقولو ا في علاقه بين مقاس رجل الر اجل و ..... مناخيره } \\
\text { byzoulu fi ‘ilaza bein mazaas rigl rilragil } \\
\text { wmanaxiru }\end{array}$ \\
\hline 58. & & Abla Fahita & $\begin{array}{l}\text { Ahmed } \\
\text { Fahmy's wife }\end{array}$ & $\begin{array}{c}\text { احمد لابس بوكسر لونه ايه lounu rih } \\
\text { جaHmad la:bbis buksr lod }\end{array}$ \\
\hline 59. & & Abla Fahita & $\begin{array}{l}\text { Ahmed } \\
\text { Fahmy's wife }\end{array}$ & $\begin{array}{c}\text { احمد عنده حسنه مستخبية فين؟ 'andu Hassana mistixabija fejn? } \\
\text { raHmad 'andu }\end{array}$ \\
\hline
\end{tabular}




\begin{tabular}{|c|c|c|c|}
\hline 60. & Abla Fahita & Ahmed Fahmy & 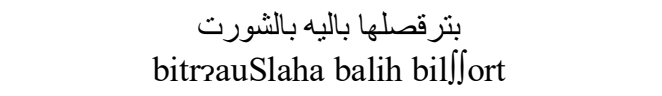 \\
\hline 61. & Abla Fahita & $\begin{array}{l}\text { Ahmed } \\
\text { Fahmy's wife }\end{array}$ & $\begin{array}{c}\text { امتي اخر مره حمادة قص اظافر رجله او قرضها؟ } \\
\text { إن rimta raaxir marra Hamada raS raZHafir riglu } \\
\text { aw raraDha }\end{array}$ \\
\hline 62. & Karo & Iyad Nassar & $\begin{array}{c}\text { مر اتك بتستلف مناك بجاماتكاتك bi3amtak } \\
\text { miratak bitstilif minak bi3am }\end{array}$ \\
\hline 63. & Karo & Iyad Nassar & $\begin{array}{c}\text { لون بيجاماتك بني ودانتيل } \\
\text { loun bi3amtak bunni w dantil }\end{array}$ \\
\hline 64. & Karo & Iyad Nassar & 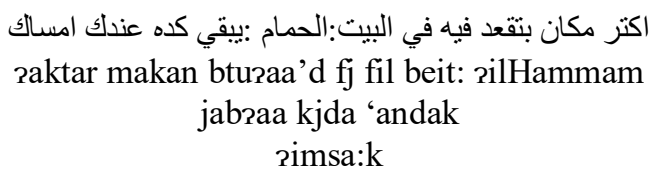 \\
\hline 65. & Abla Fahita & Iyad Nassar & $\begin{array}{c}\text { كله الاان حد يصورك يا اياد في الحمام الا الريحه ila } \\
\text { kulu rila sin Had jiSawrak fil Hammam ila } \\
\text { pilriHa }\end{array}$ \\
\hline 66. & Abla Fahita & Iyad Nassar & $\begin{array}{c}\text { بابا وماما منفصلين و لا محبوسين } \\
\text { baba wama munfaSili:n wala maHbusi:n }\end{array}$ \\
\hline 67. & Karo & Hazem Imam & $\begin{array}{c}\text { العو اهو } \\
\text { 2il'aw zahu }\end{array}$ \\
\hline 68. & Karo & Hazem Imam & $\begin{array}{c}\text { مفرد كلمه بز ابيز } \\
\text { mufrad kilmit bzabi:z }\end{array}$ \\
\hline 69. & Abla Fahita & Hazem Imam & $\begin{array}{c}\text { اموت في الابيض لما يحمر flabyad lama jiHmar } \\
\text { zamout flabyad }\end{array}$ \\
\hline 70. & Abla Fahita & Hazem Imam & 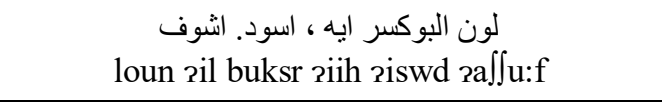 \\
\hline 71. & Abla Fahita & Hazem Imam & $\begin{array}{c}\text { جربت تلبس من قطونيل } \\
\text { garabt tilbis min qaTuni:1 }\end{array}$ \\
\hline 72. & Abla Fahita & Hazem Imam & 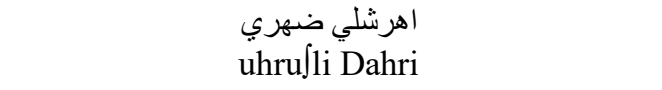 \\
\hline 73. & Abla Fahita & Hazem Imam & 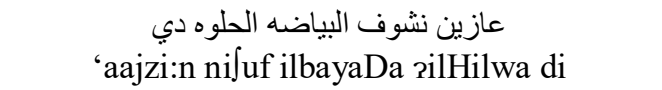 \\
\hline 74. & Abla Fahita & Hazem Imam & $\begin{array}{l}\text { فiخه } \\
\text { fa xa }\end{array}$ \\
\hline 75. & Abla Fahita & Hazem Imam & $\begin{array}{c}\text { قرطسك ياعبده 'abdu } \\
\text { 2arTaSak ja 'abdu }\end{array}$ \\
\hline 76. & Abla Fahita & Hazem Imam & l \\
\hline
\end{tabular}




\begin{tabular}{|c|c|c|c|}
\hline 77. & Abla Fahita & Hazem Imam & 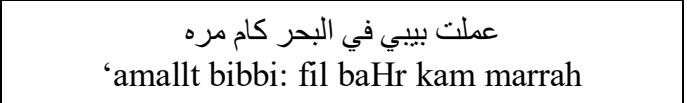 \\
\hline 78. & Abla Fahita & Hazem Imam & $\begin{array}{c}\text { اموت في الشمال } \\
\text { ramu:t fi } \iint \text { imaal }\end{array}$ \\
\hline 79. & Abla Fahita & Audience & umukum w um ili gabitkum \\
\hline 80. & Abla Fahita & Audience & $\begin{array}{c}\text { حلقة بطعم لبن السرسوب'am labban lsarsub } \\
\text { Halazaah bita'am }\end{array}$ \\
\hline 81. & Abla Fahita & Yasmin Sabry & $\begin{array}{c}\text { بلابيص } \\
\text { balaabi:S }\end{array}$ \\
\hline 82. & Abla Fahita & Yasmin Sabry & $\begin{array}{c}\text { شماعه ولا شبشب } 1 \text { شama'aa wala } \iint i b \int i b !\end{array}$ \\
\hline 83. & Abla Fahita & Yasmin Sabry & $\begin{array}{l}\text { بدلع كارو ياسخامه البرك } \\
\text { saxamit il birak }\end{array}$ \\
\hline 84. & Abla Fahita & Yasmin Sabry & يقمل \\
\hline 85. & Abla Fahita & Yasmin Sabry & $\begin{array}{c}\text { بتبوز . تكرع } \\
\text { tibawiz tikara’a }\end{array}$ \\
\hline 86. & Yasmin Sabry & Abla Fahita & $\begin{array}{c}\text { احيه } \\
\text { 2aHjh }\end{array}$ \\
\hline 87. & Abla Fahita & Yasmin Sabry & $\begin{array}{c}\text { شديتي السيفون ور الك } \\
\iint \text { adity rissifoun waraki }\end{array}$ \\
\hline 88. & Abla Fahita & Yasmin Sabry & $\begin{array}{c}\text { لعبت في مناخيرك قريب } \\
\text { l'abit fmanaxi:rk rurajb }\end{array}$ \\
\hline 89. & Abla Fahita & Yasmin Sabry & $\begin{array}{c}\text { اتفها من بؤي } \\
\text { ratiffaha min burai: }\end{array}$ \\
\hline 90. & Abla Fahita & Yasmin Sabry & 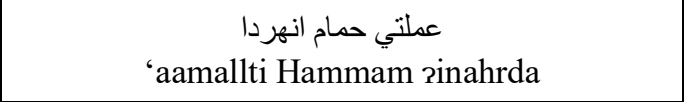 \\
\hline 91. & Abla Fahita & Zhafer Abdin & $\begin{array}{c}\text { حقائق ذي الطين لظافر عابدين 'aabdi:n } \\
\text { Haqaiziq zai elTi:n liZHafir 'aai }\end{array}$ \\
\hline 92. & Karo & Zhafer Abdin & 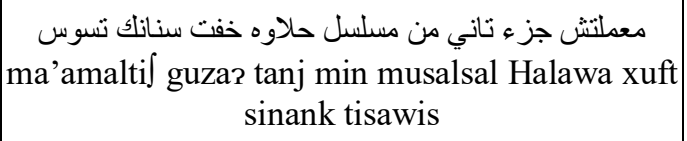 \\
\hline 93. & Karo & Zhafer Abdin & 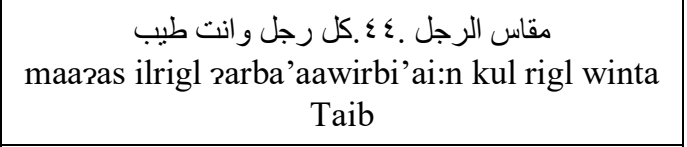 \\
\hline 94. & Karo & Zhafer Abdin & 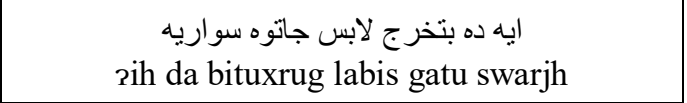 \\
\hline
\end{tabular}




\begin{tabular}{|c|c|c|c|}
\hline 95. & Abla Fahita & Zhafer Abdin & $\begin{array}{l}\text { اي منطقة بتغير فيها في جسمك } \\
\text { جaj mantiza bitghi:r fiha fi gismk }\end{array}$ \\
\hline 96. & Abla Fahita & Zhafer Abdin & $\begin{array}{l}\text { بتحب البنت اللي..... ها كبيره ha kibi:ra } \\
\text { bitHib ilbint rili... ha }\end{array}$ \\
\hline 97. & Abla Fahita & Zhafer Abdin & 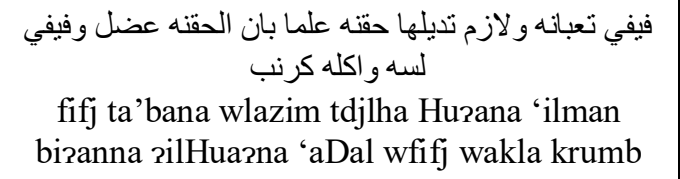 \\
\hline 98. & Abla Fahita & Zhafer Abdin & 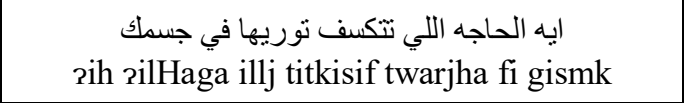 \\
\hline 99. & Abla Fahita & Rojina & $\begin{array}{c}\text { كم عدد المقاريض /شاحطة كبيره / حلوفه كبيره 'aaddad ilmazari:D / JaHTTa kbijra } \\
\text { /Halu/;fa kbijra }\end{array}$ \\
\hline 100. & Abla Fahita & Rojina & لو وقع خاتمك في القعده هاتججبيه \\
\hline 101. & Karo & Rojina & $\begin{array}{c}\varepsilon \varepsilon p^{\prime} \\
\text { sum rarba'a wirbi'ajjn }\end{array}$ \\
\hline 102. & Rojina & Karo & 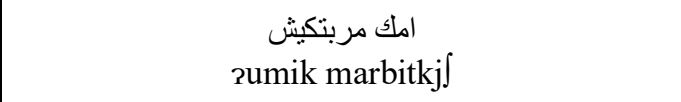 \\
\hline 103. & Abla Fahita & Rojina & 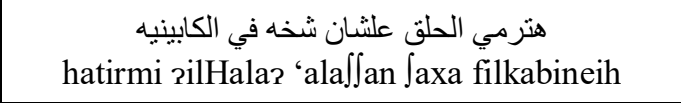 \\
\hline 104. & Abla Fahita & Audience & $\begin{array}{c}\text { مزنو } 2 \\
\text { mazznu:ra }\end{array}$ \\
\hline 105. & $\begin{array}{l}\text { Lamis } \\
\text { Elhadidy }\end{array}$ & Abla Fahita & 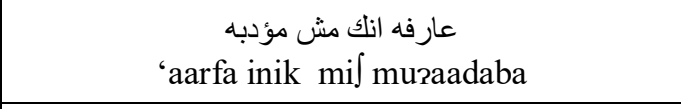 \\
\hline 106. & Karo & $\begin{array}{l}\text { Lamis } \\
\text { Elhadidy }\end{array}$ & $\begin{array}{c}\text { وراء كل انكل عظيم طنط "azheem TanT } \\
\text { waraa? kul rankle "azhem }\end{array}$ \\
\hline 107. & Karo & $\begin{array}{l}\text { Lamis } \\
\text { Elhadidy }\end{array}$ & $\begin{array}{c}\text { وور اء كل طنط عظيمة نفسها وشويه ميكب 'azhi:ma nafsaha wلwjt } \\
\text { wiwaraa? Kul Tant 'azar }\end{array}$ \\
\hline 108. & $\begin{array}{l}\text { Lamis } \\
\text { Elhadidy }\end{array}$ & Karo & $\begin{array}{c}\text { مامتلك عروسه محشية قطن 'aarusa maH]iya rutn } \\
\text { mamtik 'aarua }\end{array}$ \\
\hline 109. & Abla Fahita & $\begin{array}{l}\text { Nawal } \\
\text { Elzoghby }\end{array}$ & ja wilja \\
\hline 110. & Abla Fahita & $\begin{array}{l}\text { Nawal } \\
\text { Elzoghby }\end{array}$ & 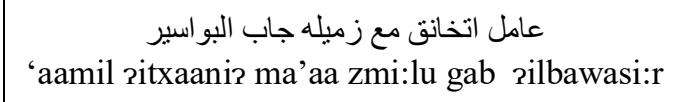 \\
\hline 111. & Abla Fahita & $\begin{array}{l}\text { Nawal } \\
\text { Elzoghby }\end{array}$ & 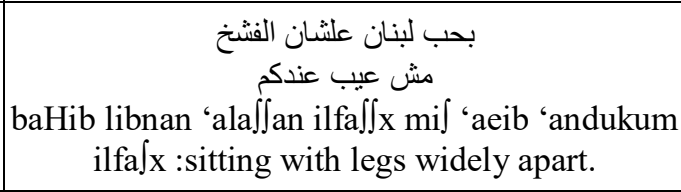 \\
\hline
\end{tabular}




\begin{tabular}{|c|c|c|c|}
\hline & & & Slang: fuck or punish severly \\
\hline 112. & Abla Fahita & $\begin{array}{l}\text { Medhat } \\
\text { Shalaby }\end{array}$ & $\begin{array}{l}\text { يابن السوكه } \\
\text { jabin 1su:ka }\end{array}$ \\
\hline 113. & Abla Fahita & $\begin{array}{l}\text { Medhat } \\
\text { Shalaby }\end{array}$ & $\begin{array}{c}\text { بالنسبة للايح ايح } \\
\text { bilnisba lilpih 2iH }\end{array}$ \\
\hline 114. & Abla Fahita & $\begin{array}{l}\text { Medhat } \\
\text { Shalaby }\end{array}$ & $\begin{array}{l}\text { اقفل رجليك } \\
\text { 2isfil riglejk }\end{array}$ \\
\hline 115. & Abla Fahita & $\begin{array}{l}\text { Medhat } \\
\text { Shalaby }\end{array}$ & $\begin{array}{l}\text { مره اتزنقت زنقة مالهاش حل } \\
\text { marra sitzannapt }\end{array}$ \\
\hline 116. & Abla Fahita & $\begin{array}{l}\text { Medhat } \\
\text { Shalaby }\end{array}$ & $\begin{array}{c}\text { ياخا شوف تو اليت } \\
\text { jaxa Jouf tuwilit }\end{array}$ \\
\hline 117. & $\begin{array}{l}\text { Medhat } \\
\text { Shalaby }\end{array}$ & Karo & $\begin{array}{c}\text { ماما قبيحه انا عارف 'aaarif } \\
\text { mama raabiHaa ana 'aaarif }\end{array}$ \\
\hline 118. & Abla Fahita & $\begin{array}{l}\text { Medhat } \\
\text { Shalaby }\end{array}$ & $\begin{array}{c}\text { عندك بوكسر مخروم 'aandak bukksr maxru:m } \\
\text { 'atakr }\end{array}$ \\
\hline 119. & Karo & Ahmed Malek & $\begin{array}{c}\text { مقصوف الرقبة } \\
\text { marSu:f riraraaba }\end{array}$ \\
\hline 120. & Abla Fahita & Ahmed Malek & $\begin{array}{c}\text { حضرتلك المحصوره } \\
\text { HaDritak rilmaHsura }\end{array}$ \\
\hline 121. & $\begin{array}{l}\text { Hasan } \\
\text { Elraddad }\end{array}$ & Abla Fahita & $\begin{array}{c}\text { علي الكبري متحير و عايز يتسبير alaa ilkubri mitHajar wi'aajiz jitsaijar } \\
\text { 'alari }\end{array}$ \\
\hline 122. & $\begin{array}{l}\text { Hasan } \\
\text { Elraddad }\end{array}$ & Abla Fahita & 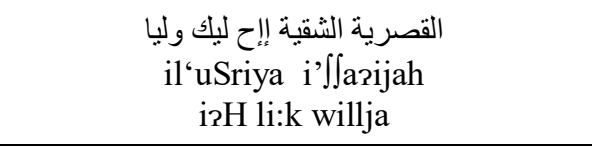 \\
\hline 123. & $\begin{array}{l}\text { Hasan } \\
\text { Elraddad }\end{array}$ & Abla Fahita & $\begin{array}{c}\text { أردافي ملظلظة } \\
\text { zardafi mlzZhlaZhah } \\
\end{array}$ \\
\hline 124. & $\begin{array}{l}\text { Hasan } \\
\text { Elraddad }\end{array}$ & Abla Fahita & قعدوه علي الخازوق?a'aaduh 'aala pilxazzou? \\
\hline 125. & $\begin{array}{l}\text { Hasan } \\
\text { Elraddad }\end{array}$ & Abla Fahita & $\begin{array}{c}\text { انشليط } \\
\text { 2it } \iint a l j a T \\
\end{array}$ \\
\hline 126. & $\begin{array}{l}\text { Hasan } \\
\text { Elraddad }\end{array}$ & Abla Fahita & Hatitnifix \\
\hline 127. & $\begin{array}{l}\text { Hasan } \\
\text { Elraddad }\end{array}$ & Abla Fahita & $\begin{array}{c}\text { يخرب بيت جمال امك 'umak } \\
\text { jixrib bijt gamal 'umak }\end{array}$ \\
\hline 128. & Abla Fahita & $\begin{array}{l}\text { Hasan } \\
\text { Elraddad }\end{array}$ & 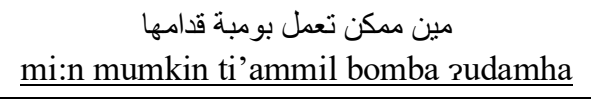 \\
\hline 129. & Abla Fahita & Hasan & حباية فاهيتا ياجر اللسعاده الزوجية \\
\hline
\end{tabular}




\begin{tabular}{|c|c|c|c|}
\hline & & Elraddad & Habajit fahita jaagra lilsa'ada rilzawgijah \\
\hline 130. & Abla Fahita & $\begin{array}{c}\text { Hasan } \\
\text { Elraddad }\end{array}$ & 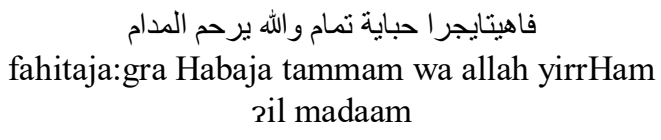 \\
\hline 131. & Abla Fahita & $\begin{array}{c}\text { Hasan } \\
\text { Elraddad }\end{array}$ & $\begin{array}{c}\text { ja marSu:f } \\
\text { ja maوف }\end{array}$ \\
\hline
\end{tabular}

